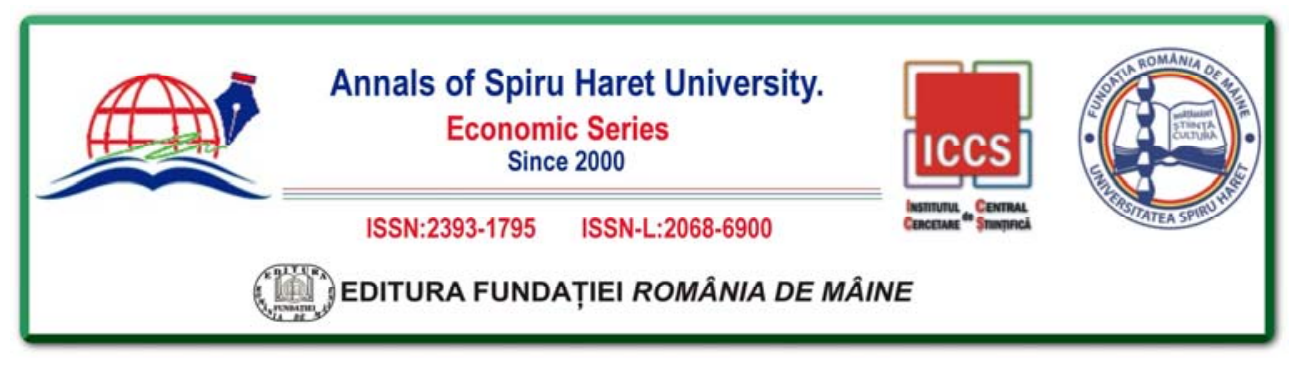

Issue $2 / 2018$

\title{
CHANGES IN THE NATIONAL STRUCTURE OF POPULATION IN THE SOUTHERN ECONOMIC REGION OF THE REPUBLIC OF MOLDOVA IN THE PERIOD 1979-2014
}

\author{
Adelina REVENCO \\ University of the Academy of Science of Moldova, Chisinau, Republic \\ of Moldova, Tel.: +37367116973, Email: revencoadelina@yahoo.com
}

How to cite: REVENCO, A. (2018). "Changes in the National Structure of Population in the Southern Economic Region of the Republic of Moldova in the Period 1979-2014." Annals of Spiru Haret University. Economic Series, 18(2), 97-115. doi: https://doi.org/10.26458/1825

\begin{abstract}
The present work has as its main objective the identification of the differences in the national structure of the population in the Southern Economic Region of the Republic of Moldova, received between 1979 and 2014 as a result of the politic and economic changes in the country, the knowledge of which plays an important role in the elaboration of strategies for social and demographic development. For the realisation of this goal a few objectives have been settled: the identification and inquiry of the speciality literature that elucidates the subject of investigation; collection, analysis and graphic and cartographic interpretation of the data collected based on the information from the National Bureau of Statistics of the Republic of Moldova, through modern means of work, programs for statistical analysis Statgraphics and Instat Plus and the SIG technique; identification and description of the impact of the historical events on the population of the territory and the diversification of the national structure; temporal clause analysis of the statistical data and the emphasize of the modification tendencies in the time lap indicated; description of the particularities of the national structure of the population at the level of administrative structure in the context of the political
\end{abstract}




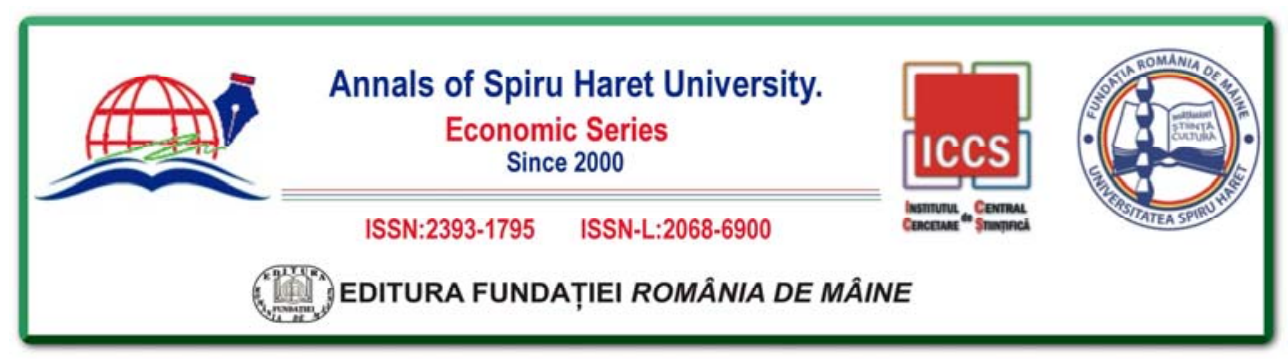

\section{Issue 2/2018}

and economic changes in that period; appreciation of the complexity of the cohabiting nationalities within the rural localities.

Keywords: national structure; ethnic groups; population of the territory; nationalities; cohabitants; rural localities.

JEL Classification: $\mathrm{J}_{11}$

\section{Introduction}

Along with the constitution of the state by the end of the $14^{\text {th }}$ century and since, the Country of Moldova has been characterised by economic stability and politics that attracted a real important number of Armenians, Hungarians, Germans, Tatars, etc., to this territory. According to Dmitrie Cantemir's narrative in the book Description of Moldova: „Besides Moldavians, in this territory, live Greeks, Albanians, Serbians, Bulgarians, Polish, Kazakhs, Russians, Hungarians, Germans, Armenians, Jewish, Roma and many more nations. Probably, there is no other village this small, in which so many nations live" [Cantemir, 1473]. Alongside the influence of various factors, the ethnic structure of the southern population changes throughout the centuries, it nevertheless remains very diverse up to this day.

The key geopolitical position of the Southern Economic Region of the Republic of Moldova, which is considered to be the gate between the Balkans and Central Europe due to the possibility to control the flow of goods on the Danube, but also the relations between the Balkan countries and the East-European ones, to whom many nations manifested great interest for this territory in history. Firstly, the attention should be drawn to the Russian nation, within these, which after the Russian-Turkish war of 1792, annexed the territories between the Dniester and the South Bug to the Russian Empire and afterwards, in 1812, with the pretext of the necessity to protect, Russian diplomats voted for the annexation of Bessarabia to the Russian Empire. Parallel to the annexation, the authorities started a campaign of modifying the ethnic composition, in this way stimulating the permanent settlement of the representatives of many nations such as Bulgarians, Gagauzes, Ukrainians, Russians, Belarus, Germans, etc., contributing essentially to the change of the ethnic composition of the population in this region.

Together with the dissolution of the Soviet Union, Moscow continued to pursue interests in this territory, stimulating and provoking separatist movements in the Republic of Moldova. Both ATUG and the Pridnestrovian Moldavian Republic 98 


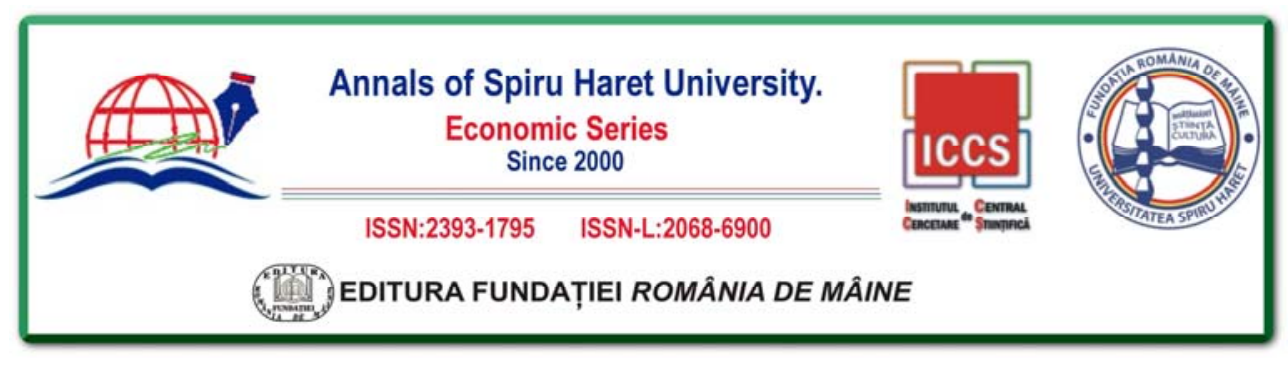

Issue $2 / 2018$

benefit until today from the protection of the Russian Federation, this way trying to keep the control of the strategic Balkan region, or trying in this way to maintain its influence on the Republic of Moldova, which serves as a buffer zone between the Russian Federation and the European Union.

One of the tools used by the authorities in this sense is the initiation of interethnic conflicts nourished mainly by the social problems with which the society fights. In this sense, the necessity of deeper research on the change of the ethnic composition of the republic generally, but also particularly of the region is needed for specific solutions regarding the re-establishment of the economic situation in the districts/regions' administrative structures.

The present paper suggests solutions for one of the important scientific questions - knowledge of the spatial distribution of nationalities, which offers the possibility to plan durably the regions, their economic and socio-economic objectives, in dependence of their ethnic demographic particularities such as: an increased birth rate in the Gagauz families and a lower one in Ukrainian and Russian families; Gagauz's tendencies to populate the rural spaces and the concentration of Ukrainians and Russians in the urban areas.

\section{Literature review}

The research on the national component of the population in the region made by: Cantemir D. [1473], Zamfir A. [1898], Nistor I. [1944], Zelenchiuk V. [1973], Kabuzan V. [1974], Zagorodnaya E., Zelenchiuk V. [1983], Zagorodnaya E., Zelenchiuk V. [1987], Matei K. [1991], Mitcu M., Hachi M. [2008], Matei C., Paladi G., Sainsus V. [2009], Matei K., Hachi M. [2014].

Aspects of the history of population of the region are exposed more detailed by Кабузан В., thus corresponding to the data published in the work Народонаселение Бессарабии и области левобережных районов Приднестровья [Kabuzan, 1974] the ethnic component of the region has essentially changed as a result of the migration, mainly to Crimea, of the nogais families that led to the depopulation of the region, creating premises for a promotional campaign of attraction of Bulgarians, Russians and Ukrainians. The same subject has been studied by many authors one of which is Zelenciuc V. in his work Население Молдавии [Zelenchiuk, 1973], Zamfir A. in Bessarabia in the $19^{\text {th }}$ Century [Zamfir, 1898] etc.

A detailed description of the basic characteristics of the population at the country level, with mentioning of the regional particularities has been made in the work The Green Book of the Population of the Republic of Moldova authors Matei 


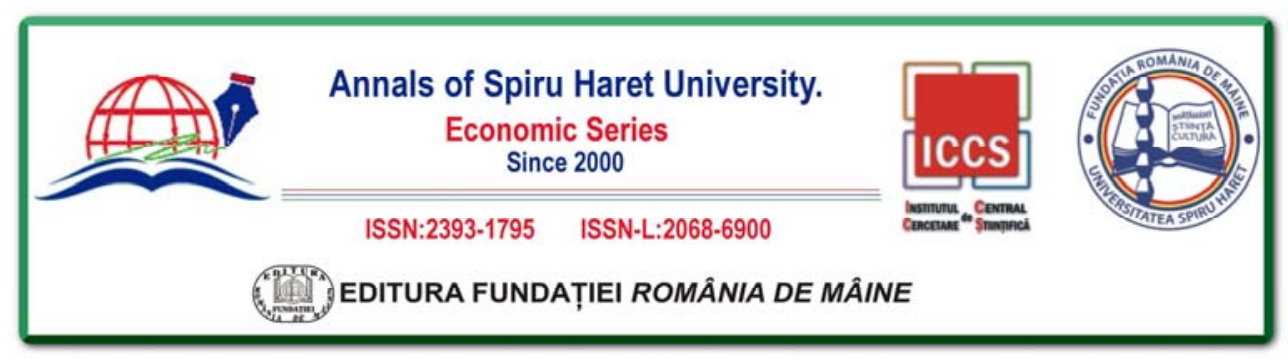

\section{Issue 2/2018}

C., Paladi G., Sainsus V. [Matei et al., 2009]. Profound examinations of the demographic component of ethnic minorities in the Republic of Moldova have been reflected by Matei C., Hachi M. [Matei \& Hachi, 2014] in the publication Demographic Evolution of the Republic of Moldova.

\section{Theoretical background}

The present study has been made in accordance to the data offered by the National Bureau of Statistics of the Republic of Moldova, in which the data regarding the number, demographic characteristics, national composition, etc. is presented, but also of those offered by the Archive of the National Bureau of Statistics regarding the ethnic structure of the population in the rural areas of the region. The collected data refers to eight administrative districts, an autonomous region and 325 rural localities and include the research period between 1979 and 2014.

The analysis of the information has been realised with the help of programs processing the statistical data. In the initial work phase everything has been done in a Microsoft Excel (a component of the Microsoft Office Professional) data base in a tab form with a structure on years, ethnics, administrative unit, and rural area. In the next phase, the statistical processing of the information and its graphic and spatial representation has been done with the help of Statgraphics, Instat Plus and ArcGis.

The present research has been done through modern transversal analytical methods, but also with the traditional ones, out of which the statistical remaking, map-drawing, spatial-temporal estimation through a repeated usage of historic, deduction, comparison, analysis and synthesis, etc. have a great importance.

For the calculation of central values, of variation index (maximal and minimal values, the variation amplitude, etc.) programs of statistical analysis and graphic representation were used (Statgraphics and Instat Plus).

In the maps' elaboration, the methods of statistical tests were used along with SIG (Sistem Informatic Geografic - Geographic Information System) techniques, more specifically the ArcGis10.2.2 programs, with the help of which the final data was modelled through many interpolation methods (Spline, IDW, Kriging).

\section{Paper content}

The Republic of Moldova in general and the Southern Economic Region particularly is characterised by a heterogeneous national structure, determined by the history of the population of the territory, in the same time the population of 


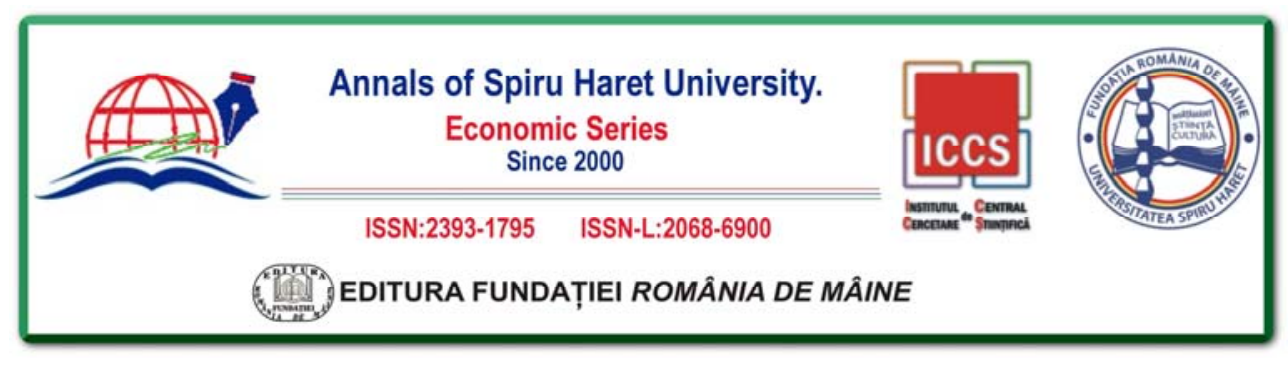

Issue $2 / 2018$

Romanian origins formed the prevalent part in the past, but in the actual stage as well, representing on average on the regional level around 62\% in 1979 and approximately $65 \%$ in 2014 . A special effect on the ethnic structure emerged due to the historic events in different periods, time within which frequent borders modifications and massive migrations of the nomad people occurred and no strict evidence of the population were conducted, reasons why scientific research was done with difficulties.

The impact of historic events on the population and diversification of the national structure of population in the Southern Economic Region

One of the first interventions into the national population structure takes place between the $16^{\text {th }}$ and the $18^{\text {th }}$ centuries, when Moldova as a state is taken under the rule of the Ottoman Empire, which in the second half of the $16^{\text {th }}$ century forced the nomad nogaic population to settle into the Bugeac Steppe. Gradually they moved into the centre of the territory occupying by 1672 the territories until the ,Xililpasha" line (situated a little bit further than the upper Valul lui Traian) and the Botna River, but after the loss of the Moldavian army in 1711, they extended their territories even more to the north. In this way, between the ' 60 s and the ' 70 s of the $18^{\text {th }}$ century, the Turkish rayas (territories held under the direct administration of the Ottoman Empire) partially populated by nogais constituted $1 / 4$ of the whole Moldova [Zagorodnaya \& Zelenchiuk, 1987] and the whole examined territory.

An important modification into the ethnic structure of the region takes place within 1770 and 1776, when the Russian army wins the Turkish and the Russian government forces the nogais settled in the Bugeac to evict, relocating them in the Caucasus and some of the regions in Novorussia [Mohov, 1961]. According to the research done by the scientists Zelenchiuk V. and Karbuzan V., until 1806 approximately 17 thousand families of nogais were forced to move [Zelenchiuk, 1973]. As a result, a massive depopulation of the region occurs and the Russian government stimulates solutions for this problem through: free land possession; exemption from taxation for certain periods of time; liberation from the military service, etc. In consequence, immigrants from the Russian Empire and European countries move to the Bugeac. For example, between 1772 and 1774 here settled approximately 400 Serbian families [Bachinskii, 1966]. In the same time, the government of the Russian Empire develops a policy of forced population of the territories through imposing the countrymen from Russian provinces to move here.

The loss the Russians experienced in the Russian-Turkish war in 1807-1812, attracts after it a flood of Bulgarians into the Bugeac Steppe because they were afraid 


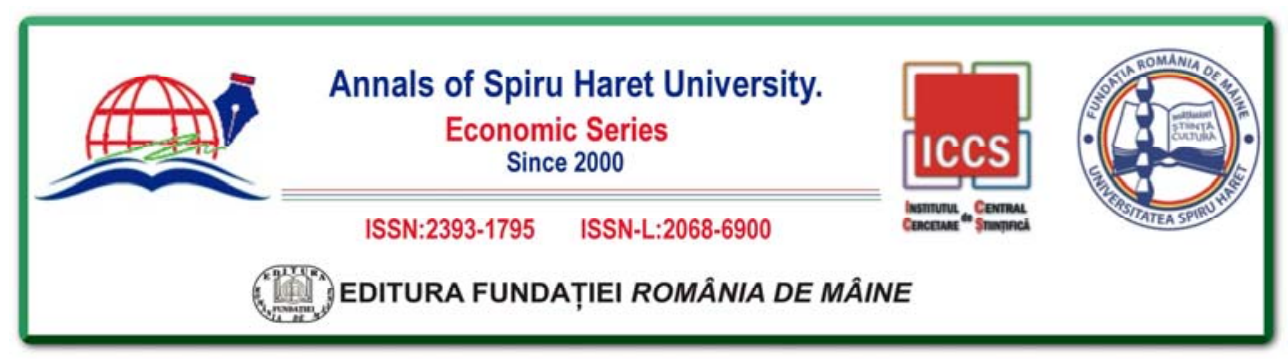

\section{Issue 2/2018}

not to be punished by the Turkish for helping the Russians in the war [Nistor, 1944]. It's important to say that the Russian tsar Alexander the It appreciates the Bulgarians and on December $28^{\text {th }}, 1819$ emits a decree to the Bulgarian colonists from the tsarist Bessarabia which gives them rights and certain facilitation: the status of colonists to the transdanubian immigrants, the allotment with 60 tithes to those who had no land; exemption from any taxation and labour conscription to the state for 7 years; liberation from the military service and liberties concerning culture and traditions. The policy results in an increase in the number of transdanubian descendants settled within the territories given to the immigrants. Thus, in 1823, a census was conducted which resulted with an official data of 550.000 inhabitants, 161,000 more than in the official data from 1818 [Arbure, 1898].

Despite the fact that this region was populated by a huge number of foreigners (Albanians, Serbians, Bulgarians, Ukrainians, Russians, Germans, Gagauzes, Roma, etc.), still the locals constituted the majority of the population, fact confirmed by statistical data presented by the Russian scientist L. K. Berg, who estimates the number of population of Romanian origins to approximately 920.9 thousands, which represents almost $47.8 \%$ of the total of the population in 1897 [Berg, 1918].

The historic events that took place right after contributed to the change of the national component of the territory, determining some nations to leave, and other to re-establish here.

Another period that marked the ethnic structure matches with the Soviet era, when within the region, as well as in the whole country, the idea of a diverse ethnic structure and denationalisation is being promoted. The authorities encourage the migration of the population within the republics in the union, mixed marriages, opening of Russian schools, etc. As a result, the density of Russians, Ukrainians, Belarus increases.

Therefore, in the process of populating the territories many different nations were actively participating, such as Gagauzes, Bulgarians, Russians, Ukrainians, Germans, Jewish, Roma, etc., thus actually the south is characterised by the most diverse ethnic structure compared to other regions of the country.

The analysis of the evolution of the national structure of population in the region between 1979 and 2014

The analysis of the national structure of the population in the region between 1979 and 2014 was realised under the census offered by the National Bureau of Statistics. According to them, within the region, the Moldavians who cohabit with 


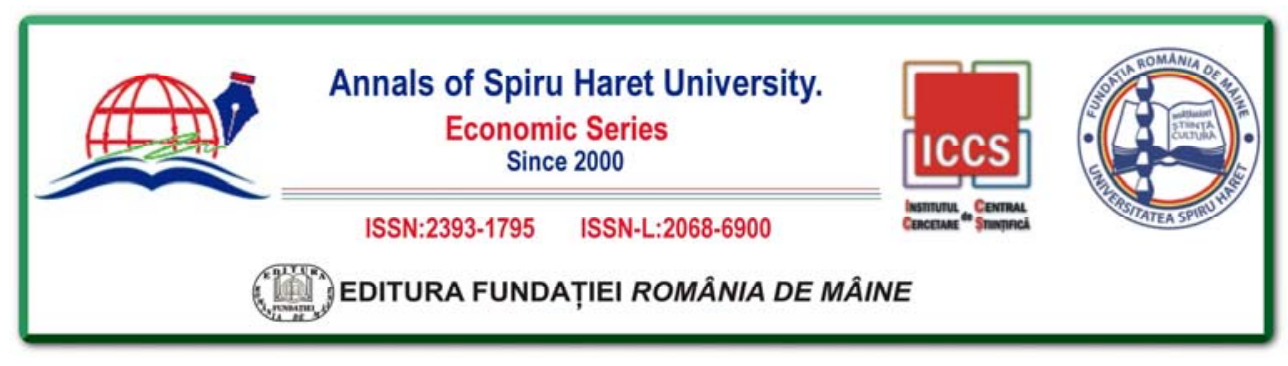

Issue $2 / 2018$

the Gagauzes, Bulgarians, Russians, Ukrainians, Germans, Jewish, Roma, etc. prevail. The confronting data from 1979 and 2014 exposed in tab. 1 emphasise the following ethnic proportion variations:

$\checkmark$ increases in case of: Moldavians with $2.84 \%$, Gagauzes with $2.96 \%$, Bulgarians with $4.62 \%$, Romanians with $4.67 \%$, Gypsies with $0.07 \%$;

$\checkmark$ decreases in case of: Russians with $0.67 \%$, Ukrainians with $1.99 \%$, Jewish with $0.2 \%$, Byelorussians with $0.13 \%$, Germans with $0.14 \%$.

Moldavians have the most stable situation, whose percentage increased throughout the whole period, but with the fall of the socialist system and the gain of the liberty for speech, an increased number of people declared themselves as being Romanians. Thus, if in 1979 approximately $62.32 \%$ of the population declared themselves Moldavians, then by 1989 their proportion increased with $2.68 \%$. Afterwards, in the period between 1989 and 2004, we can note an increase of $2.21 \%$ of those who consider themselves Moldavians plus $1 \%$ of the population who declared themselves Romanians, in this way the total increase would be of $3.21 \%$. For the period between 2004 and 2014, we can testify just the proportion of the population who declare themselves Romanians with $3.76 \%$.

The percentage rate of the Gagauzes increases between 1979 and 1989 with approximately $4.21 \%$, followed by a period of decrease with $1.4 \%$ (1989-2004) and again an increase with $0.14 \%$ in the following decade.

The Bulgarians' proportion increases constantly until 2004, in 1989 with $3.20 \%$, compared to 1979 and with $1.64 \%$ in 2004 in comparison to 1989 , while at the last census (2014) a decrease of $0.22 \%$ occurs.

A more specific situation is assigned to the Roma, who though attest, in the examination period, an increased proportion with $0.07 \%$, still don't register a constant active dynamic, thus, if in 1979 they represent $0.24 \%$, by 2014 they only record $0.31 \%$.

Other cohabitant nationalities are characterised by an ongoing decrease, thus even though the proportion of Russians and Ukrainians grows between 1979 and 1989 with approximately $1.46 \%$ and $0.26 \%$ respectively (apart because of the migration of experts from the ex union republics), after the fall of the Soviet Union, because of the economic and political instability, but also because of an increased attractiveness of the mother lands [Mitcu \& Hachi, 2008], a big part of the population emigrates, thus the number of Russians between 1989 and 2014 decreases with 2.13\%, of Ukrainians with $2.23 \%$, and other nations such as: Jewish, Byelorussians, Polish, Germans are testified in a very small number, becoming not significant from the statistical point of view. 


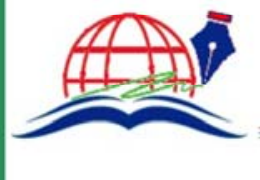

Annals of Spiru Haret University.

Economic Series

Since 2000

ISSN:2393-1795 ISSN-L:2068-6900
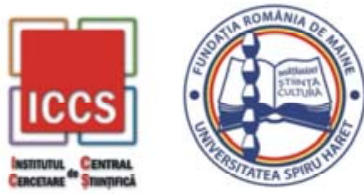

EDITURA FUNDAṬIEI ROMÂNIA DE MÂINE

\section{Issue 2/2018}

The ethnic structure of the region is determined mainly by the natality rate specific to the nationalities, which in 1979 constitutes, on average for the whole country, 19.4\%, assigned to nationalities as: 21.1 - Gagauzes; 20.6 - Moldavians; 17.9 Bulgarians; 17.5 - Ukrainians; 15.4 - Russians [Zagorodnaya \& Zelenchiuk, 1983].

Table no. 1. The ethnic structure of the Southern Economic Region, 1979-2014, \%

\begin{tabular}{|r|r|r|r|r|r|r|r|r|r|r|r|}
\hline & moldovans & găgăuzes & bulgarians & russians & ukrainians & romanian & hebrew & belarusian & german & gypsies & more \\
\hline 1979 & 62,32 & 8,76 & 6,07 & 4,33 & 5,29 & 0,00 & 0,2 & 0,13 & 0,14 & 0,24 & 0,4 \\
\hline 1989 & 65,10 & 12,97 & 9,27 & 5,79 & 5,65 & 0,00 & 0,4 & 0,10 & 0,2 & 0,11 & 0,3 \\
\hline 2004 & 67,31 & 11,57 & 10,91 & 4,27 & 4,22 & 1,00 & 0 & 0 & 0 & 0 & 0,7 \\
\hline 2014 & 65,16 & 11,72 & 10,69 & 3,66 & 3,42 & 4,67 & 0 & 0 & 0 & 0,31 & 0,4 \\
\hline
\end{tabular}

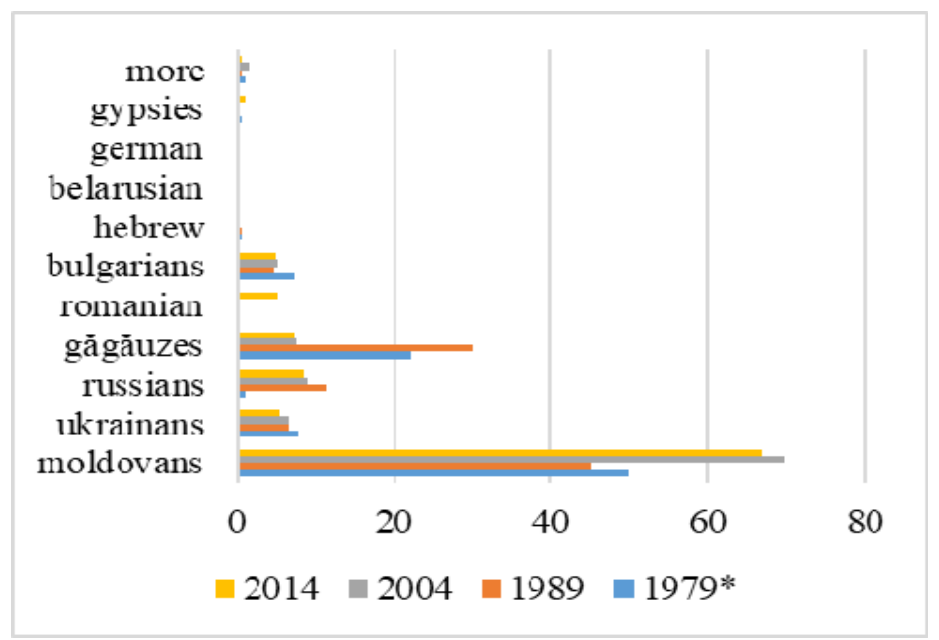

Figure no. 1. The ethnic structure of Basarabeasca distinct between 1979 and 2014

Corresponding to the data from the National Bureau of Statistics, for 2014, in the prolificacy top, the same nations prevail, thus the biggest number of children registered on one childbearing woman is noted to women who declared themselves as being Roma (for 1,000 women who are 15 years old over 1,883 children are 104 


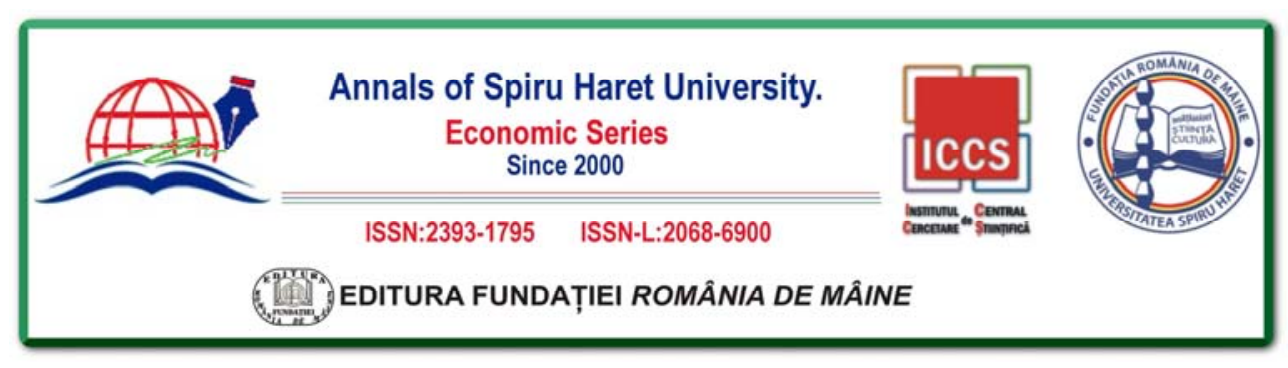

Issue $2 / 2018$

born), followed by those who declared themselves Gagauzes with 1,765 children, Moldavians with 1,672 children and Russians with 1,387 children.

It's important to mention that high natality rates are specific for the Gagauzes until now, influenced by the living mainly in the rural regions, a low level of education in women and cultural characteristics of this nation.

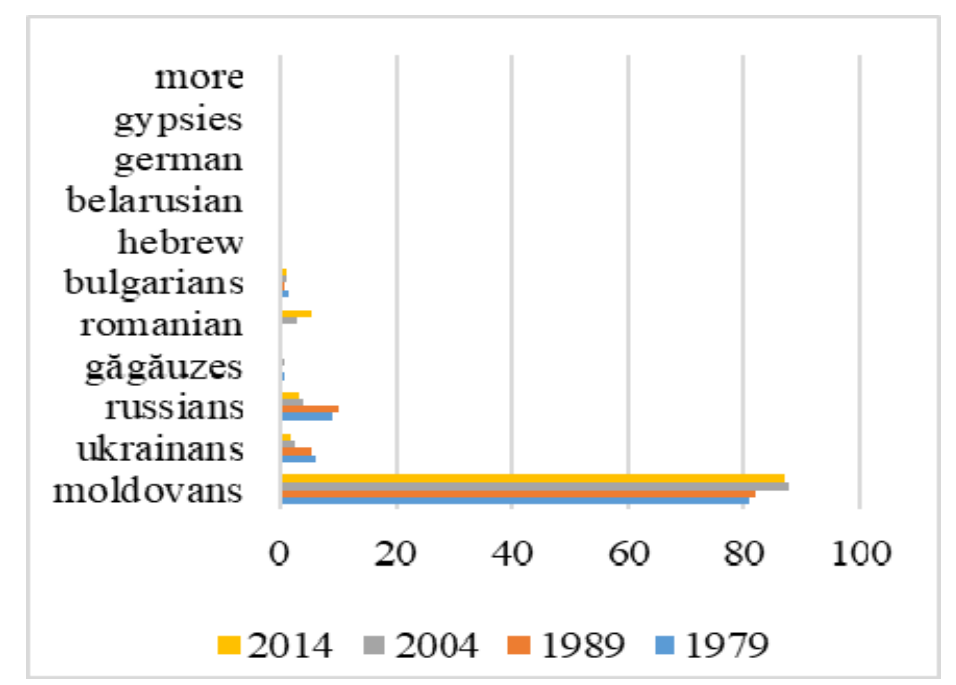

Figure no. 2. The ethnic structure of Cauşeni distinct between 1979 and 2014 level

The dynamic of the national structure of population at the administrative entity

The analysis of the ethnic structure at the level of administrative districts emphasises the predominance of Moldavians in all the districts with the exceptions of ATUG and Taraclia. It is necessary to mention that the Basarabesca (figure no. 1), Caușeni (figure no. 2), Cimișlia (figure no. 3), Ștefan Vodă (figure no. 4), Leova (figure no. 5), Cahul (figure no. 6), Cantemir (figure no. 7) districts during the whole period of examination the proportion of Moldavians increases. 


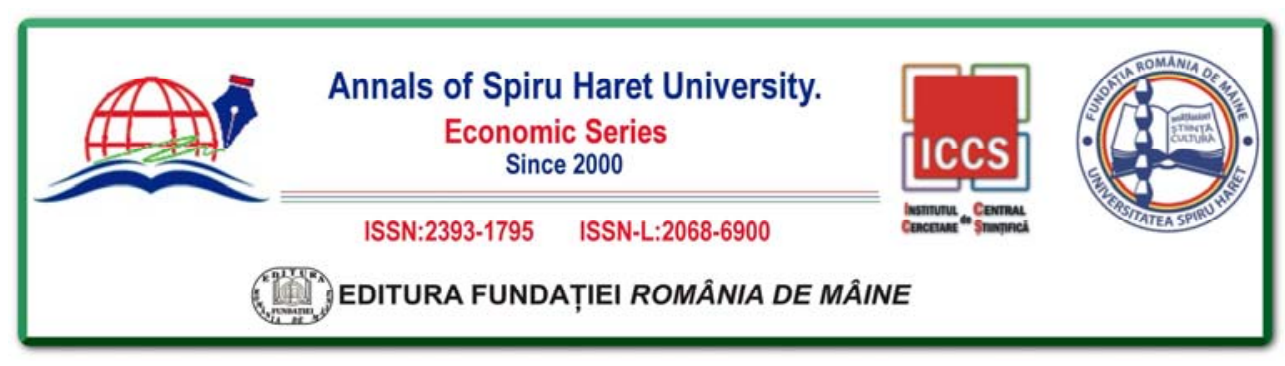

Issue 2/2018

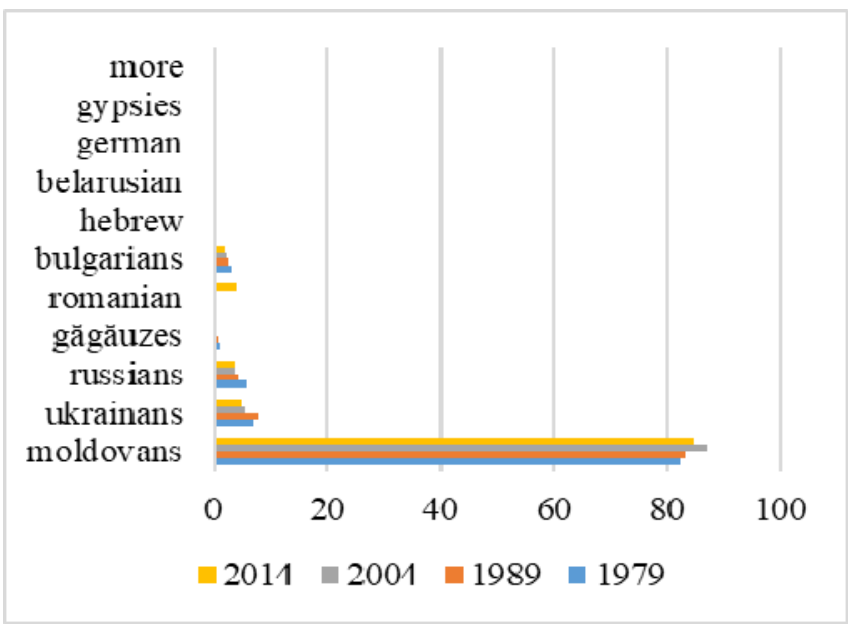

Figure no. 3. The ethnic structure of Cimișlia distinct between 1979 and 2014

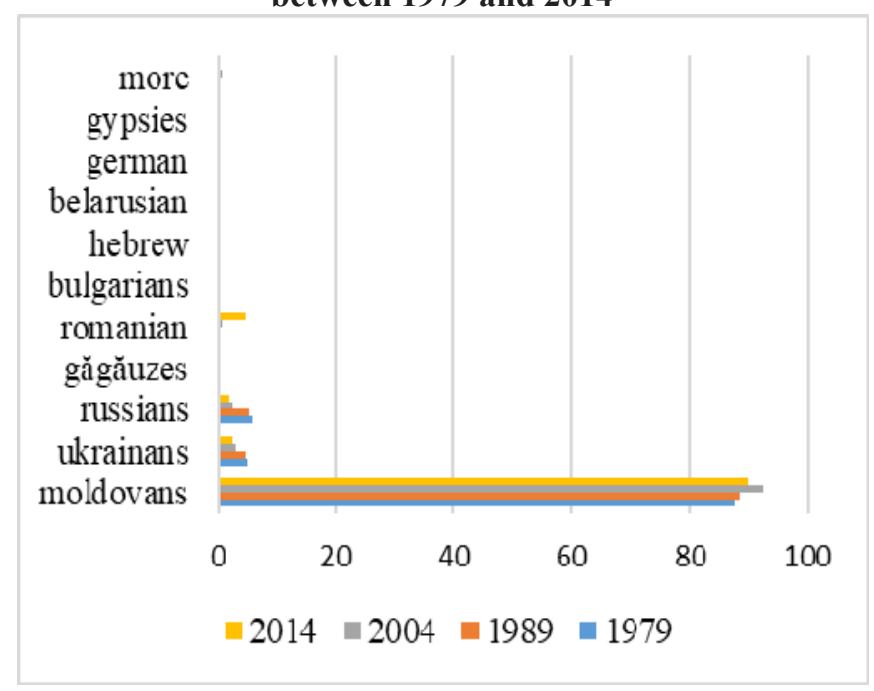

Figure no. 4. The ethnic structure of Ștefan Vodă distinct between 1979 and 2014 


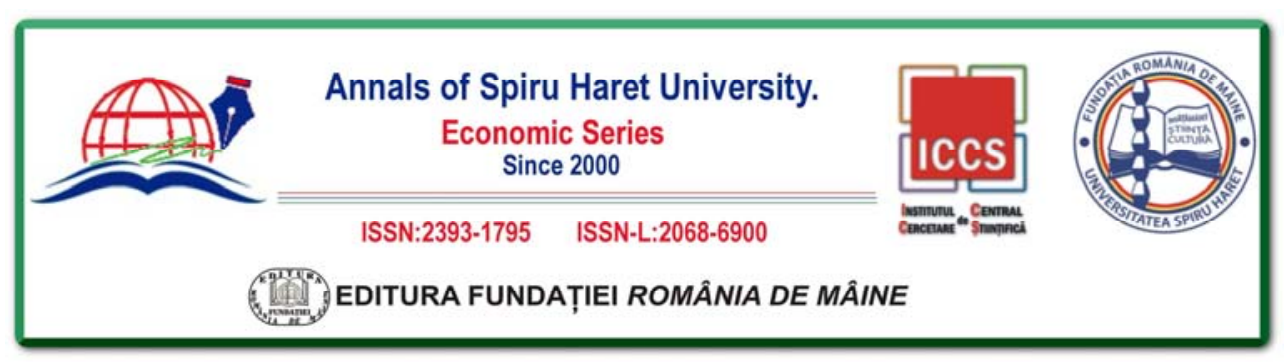

Issue $2 / 2018$

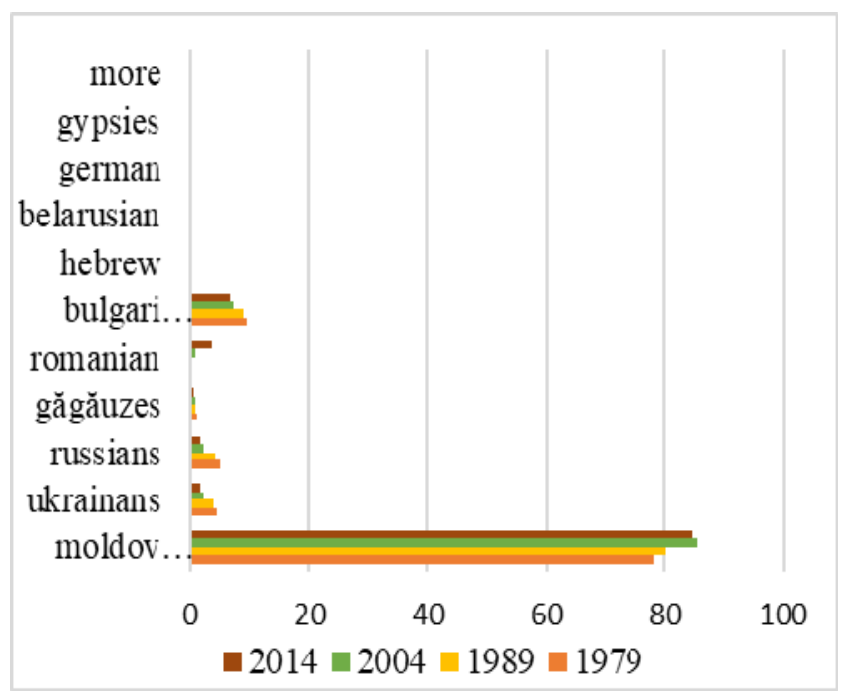

Figure no. 5. The ethnic structure of Leova distinct between 1979 and 2014

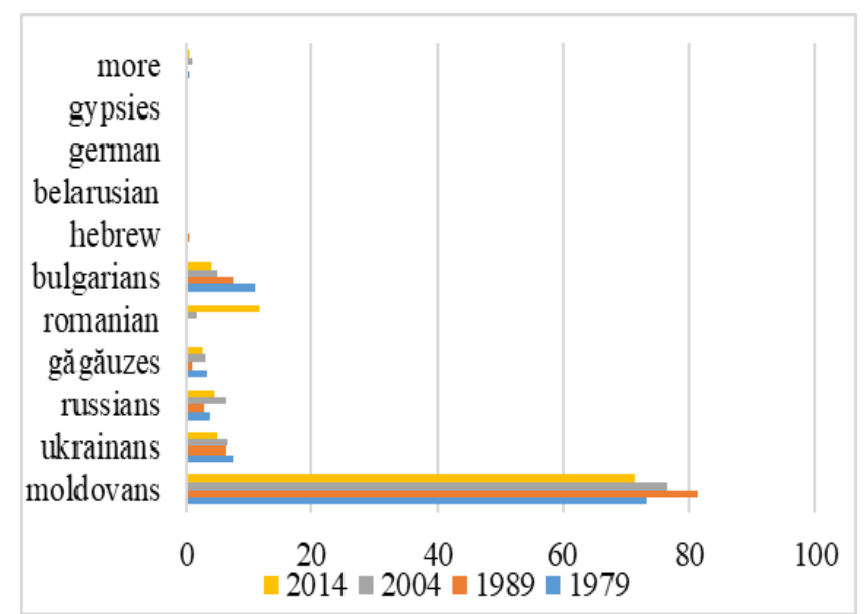

Figure no. 6. The ethnic structure of Cahul distinct between 1979 and 2014 


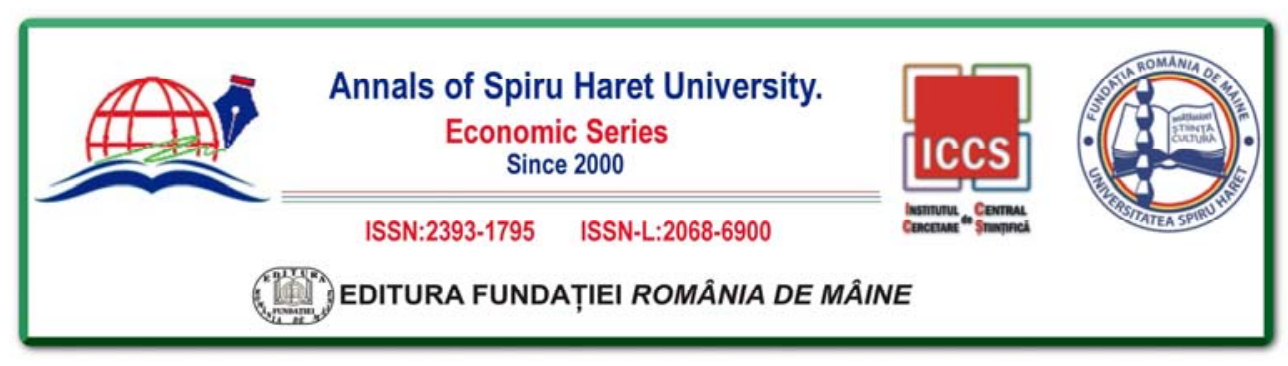

\section{Issue 2/2018}

The smallest increase registered in the case of Ștefan Vodă with approximately $2.07 \%$, but the smallest is specific for the Basarabeasca district with $17.3 \%$. In the Cantemir and Cahul districts, the proportion of Moldavians decreases, but once Moldova gains its independence (1991) the proportion increases with the same values as the proportion of population who declare themselves Romanians (with 0,16 and respectively 1,86 ).

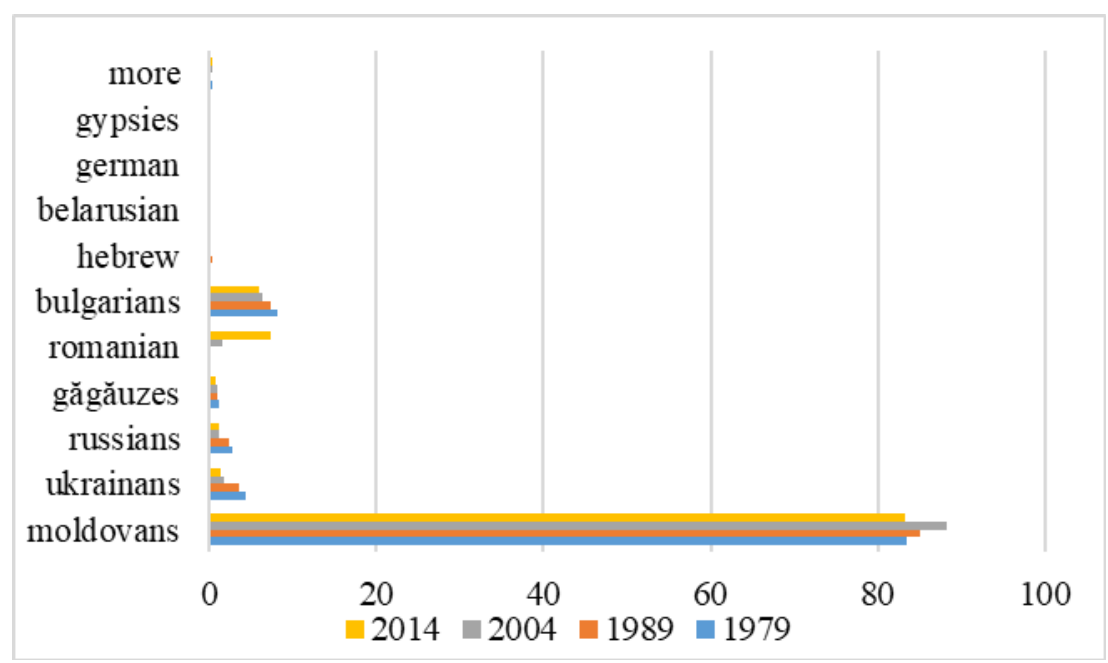

Figure no. 7. The ethnic structure of Cantemir distinct between 1979 and 2014

While examining the proportion of other ethnicities in the national structure of the administrative units of the region's population, it can be concluded that the referred period does not sum up more than $10 \%$ of the total population, moreover, after 1989 it is in decline. Similarly, from 1989 to 2014, the proportion of Ukrainian ethnicities decreased by variable values of $0.7-5.65 \%$ (with the exception of the Basarabeasca district, where a growth of 7.78\% can be observed); the Gagauzian one diminishes with included values of $0.5-18.51 \%$; the Bulgarian by $0.03-6.86$ (excluding Basarabeasca district, which experienced growth since the formation of ATUG with the average of $25.91 \%$ ). 


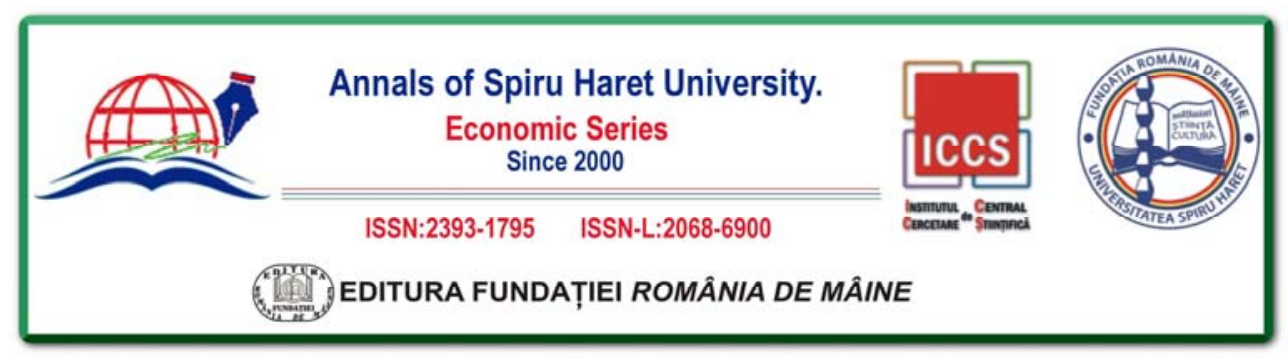

Issue $2 / 2018$

The analysis of the ethnic spatial repartition highlights the fact that the biggest changes manifested themselves in the same time with the dissolution of the socialist system and proclamation of the independence. Thereafter, the analysis of figure no. 8 and 9 underline the up growth of the proportion of Gagauz in ATUG and of Bulgarians in Taraclia, as well as the lowering of the proportion of other ethnicities in all the administrative units. Upstarted modifications are explained by the deep economical and political crisis in which the Republic of Moldova is drowning beginning with 1991, the abrupt provocation of war by the separatist structures, encouraged by the government of Russian Federation and the intense national movement of Romanians/Moldavians in 1991-1993. As a consequence, besides the decrease in density of the Gagauzes in ATUG and of Bulgarians in Taraclia district, the migration of Russian, Ukrainian, German, Jewish ethnicities back to their country of origin, which are characterised by a higher economical potential is more attractive for the population [Matei et al., 2009].

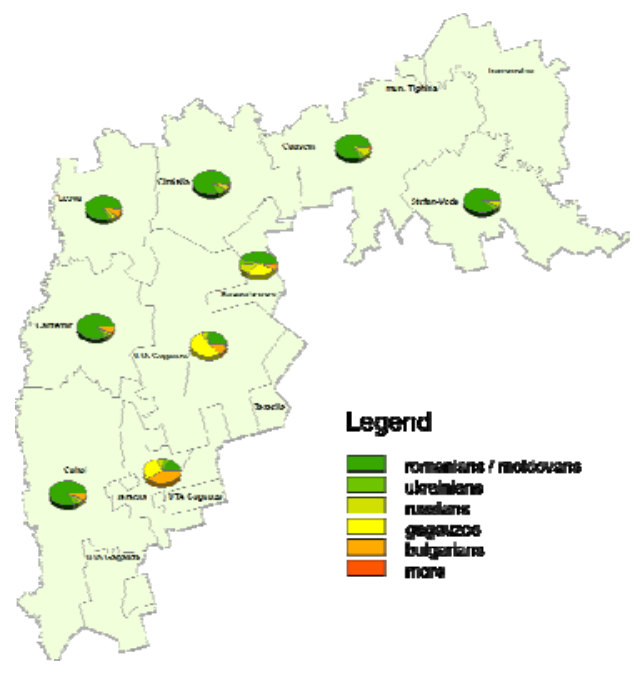

Figure no. 8. Ethnic distribution in $\mathbf{1 9 8 9}$ at level of administrative structures

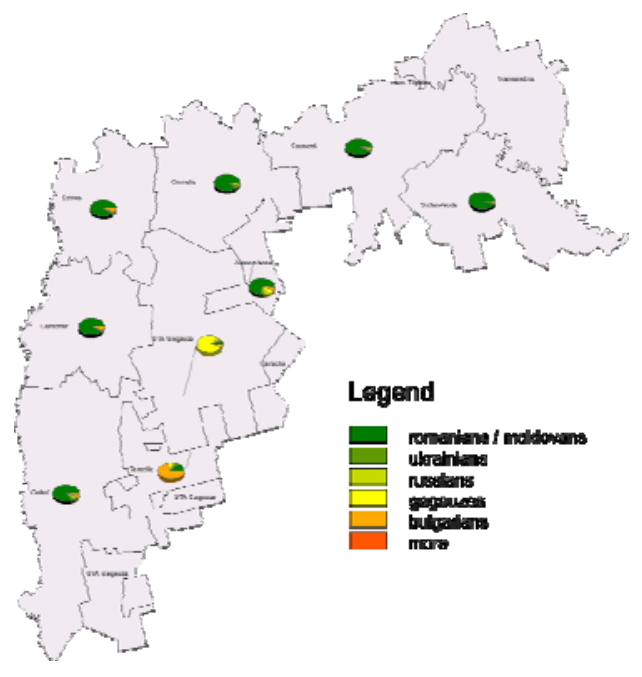

Figure no. 9. Ethnic distribution in 2014 at level of administrative structures

Two of the administrative units of the region are characterised by the predominance of other ethnicities than Moldavians. In Taraclia district (figure no. 


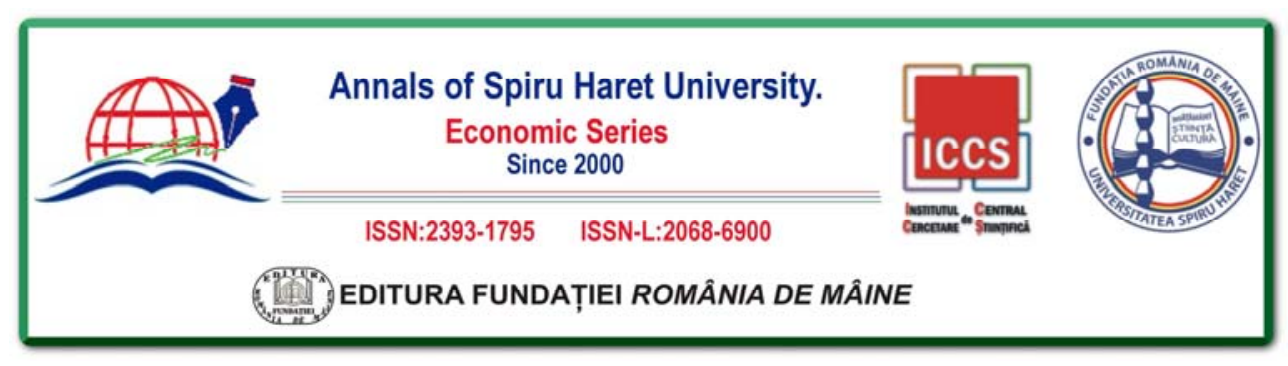

\section{Issue 2/2018}

10) the proportion of Bulgarians equals $66.11 \%$, growing by $25.91 \%$ comparing to 1991 (Taraclia was not even existing in 1979, the localities included today into its component were part of Cahul, Vulcănești and Ceadîr Lunga before).

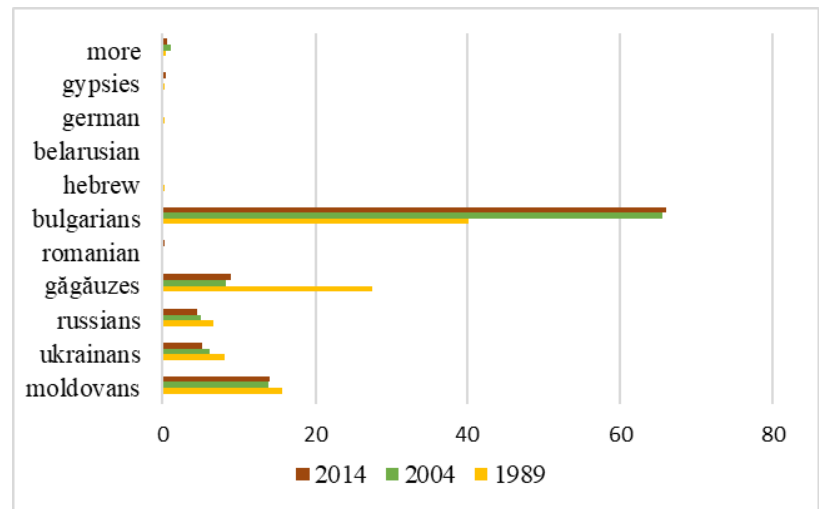

Figure no. 10. The ethnic structure of Leova district between 1979 and 2014

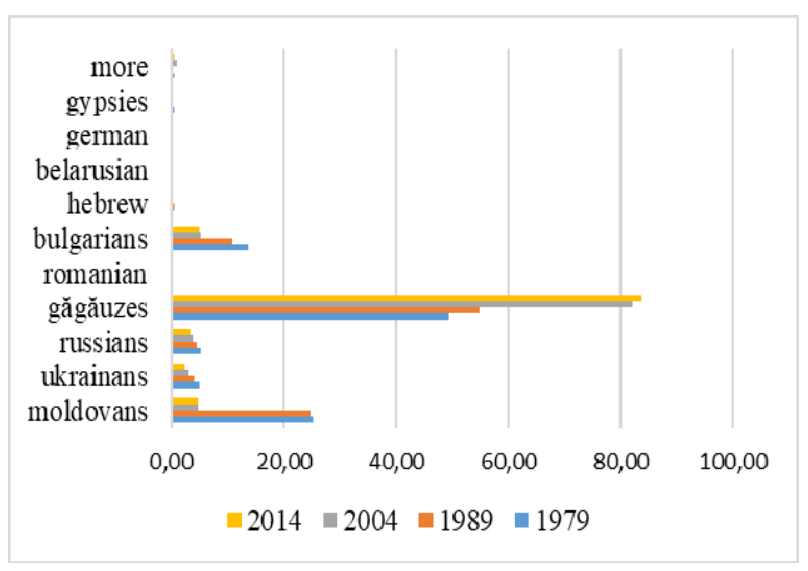

Figure no. 11. The ethnic structure of ATUG between 1979 and 2014 


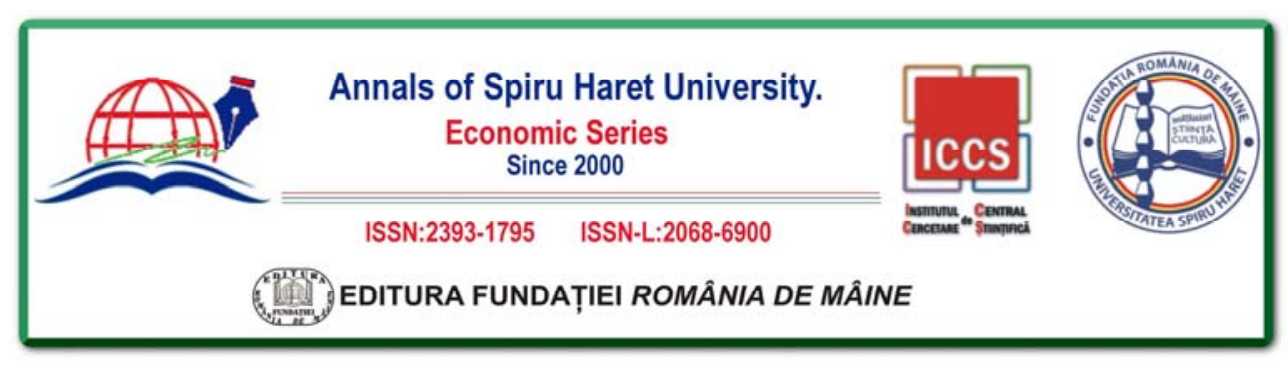

Issue $2 / 2018$

In ATUG (figure no. 11) the Gagauz are the big majority of $83.78 \%$, by $34.32 \%$ more than in 1979 (in 1979 their density was 49.47\%). The data of 1979, 1989 were ensued from the percentage share of Gagauzes observed in Ceadâr Lunga, Comrat and Vulcănești districts.

The ethnic groups' distribution on the rural localities level

The analysis of the ethnical composition of the rural localities of the region stresses the successful cohabitation of representatives of different ethnicities, ascribed to high level of tolerance demonstrated by the local population. Therefore, in $98.14 \%$ of the cases, the localities are multinational and just $1.85 \%$ are homogeneous (all being 100\% formed of Moldavians): Suhat, Craciun, Popovca from Cantemir district; Ursoaia Nouă and Ștefănești from Caușeni district; Victoria from Leova district.

In $65.4 \%$ of the localities, Moldavian ethnics constituted over $60.01 \%$ of the total population. At the other extreme are the Jewish, Roma and Polish, which in $100 \%$ of cases form up to $10 \%$ of total population of the localities.

The data regarding the level of concentration of ethnic groups within the limits of the rural localities at the level of administrative units are too overviewed in table no. 2.

Approximately $91.98 \%$ of Russians, $84.57 \%$ of Ukrainians, $82.72 \%$ of Bulgarians and $82.10 \%$ of Gagauzes live scattered, forming up to $10 \%$ of the total local population and just in some cases their density exceeds $60 \%$. The localities in which Russians sum up more than $60 \%$ of the total population constitute $0.93 \%$ of the total localities inhabited by Russians, such as Zviozdocica (Căușeni), Troițcoe (Cimișlia), Semionovca (Ștefan Vodă). In 1.85\% of the total inhabited localities by Ukrainians, their proportion exceeds $60 \%$, for instance in: Bogdanovca Veche, Bogdanovca Nouă, Albina (Cimișlia district), Brezoaia (Ștefan Vodă), Musaitu (Taraclia), Cîșla (Cantemir). In the following localities: Stoianovca, Taraclia (Cantemir), Constantinovca (Căușeni), Dimitrovca (Cimişlia), Troița, Colobabovca, Vozneseni, Troian (Leova), Corten, Cairaclia, Valea Perjei, Cortenul Nou, Albota de Jos (Taraclia), over $60 \%$ of population of Bulgarian ethnicity is concentrated and represents $4.63 \%$ from the total localities inhabited by Bulgarians. 


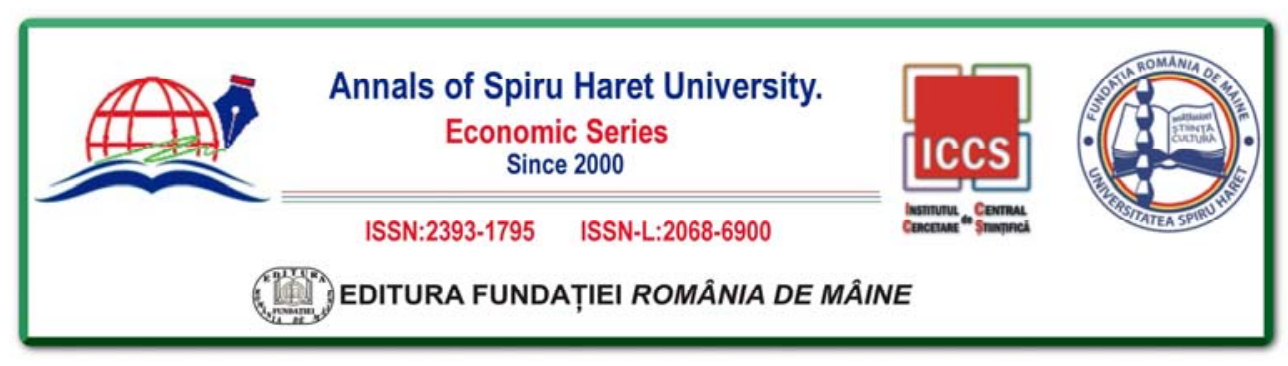

\section{Issue $2 / 2018$}

Table no. 1. The repartition of ethnicities at the local level, 2014

\begin{tabular}{|c|c|c|c|c|c|c|c|c|c|}
\hline & $\begin{array}{l}\text { Percentage } \\
\text { of } \\
\text { ethnicities, } \\
\%\end{array}$ & $\begin{array}{l}\text { romanian } / \\
\text { moldovans }\end{array}$ & russians & ukrainians & bulgarians & găgăuzes & hebrew & gypsies & polish \\
\hline \multirow[t]{4}{*}{ Basarabeasca } & $0-10$ & 1 & 9 & 7 & 7 & 7 & 10 & 10 & 10 \\
\hline & $10.01-30$ & 1 & 1 & 2 & 3 & 2 & & & \\
\hline & $30.01-60$ & 3 & & 1 & & & & & \\
\hline & $60.01-100$ & 5 & & & & 1 & & & \\
\hline \multirow[t]{4}{*}{ Cahul } & $0-10$ & 0 & 52 & 39 & 48 & 50 & 55 & 55 & 55 \\
\hline & $10.01-30$ & 2 & 3 & 12 & 3 & 1 & & & \\
\hline & $30.01-60$ & 13 & & 4 & 4 & 4 & & & \\
\hline & $60.01-100$ & 40 & & & & & & & \\
\hline \multirow[t]{4}{*}{ Cantemir } & $0-10$ & 0 & 51 & 50 & 44 & 49 & 51 & 51 & 51 \\
\hline & $10.01-30$ & 2 & & & 2 & 2 & & & \\
\hline & $30.01-60$ & 3 & & & 3 & & & & \\
\hline & $60.01-100$ & 46 & & 1 & 2 & & & & \\
\hline \multirow[t]{4}{*}{ Căușeni } & $0-10$ & 3 & 37 & 39 & 43 & 44 & 45 & 45 & 45 \\
\hline & $10.01-30$ & 2 & 4 & 4 & 1 & & & & \\
\hline & $30.01-60$ & 7 & 3 & 2 & & & & & \\
\hline & $60.01-100$ & 33 & 1 & & 1 & 1 & & & \\
\hline \multirow[t]{4}{*}{ Cimișlia } & $0-10$ & 1 & 37 & 33 & 36 & 39 & 39 & 39 & 39 \\
\hline & $10.01-30$ & 5 & 1 & 3 & & & & & \\
\hline & $30.01-60$ & 1 & & & 2 & & & & \\
\hline & $60.01-100$ & 32 & 1 & 3 & 1 & & & & \\
\hline \multirow[t]{4}{*}{ Leova } & $0-10$ & 3 & 40 & 36 & 31 & 38 & 40 & 40 & 40 \\
\hline & $10.01-30$ & 3 & & 2 & 3 & 2 & & & \\
\hline & $30.01-60$ & 3 & & 2 & 2 & & & & \\
\hline & $60.01-100$ & 31 & & & 4 & & & & \\
\hline \multirow[t]{4}{*}{ Ştefan Vodă } & $0-10$ & & 23 & 24 & 26 & 26 & 26 & 26 & 26 \\
\hline & $10.01-30$ & 2 & 2 & & & & & & \\
\hline & $30.01-60$ & 2 & & 1 & & & & & \\
\hline & $60.01-100$ & 22 & 1 & 1 & & & & & \\
\hline \multirow[t]{4}{*}{ Taraclia } & $0-10$ & 5 & 19 & 19 & 3 & 12 & 26 & 26 & 26 \\
\hline & $10.01-30$ & 12 & 7 & 4 & 11 & 8 & & & \\
\hline & $30.01-60$ & 6 & & 2 & 5 & 6 & & & \\
\hline & $60.01-100$ & 3 & & 1 & 7 & & & & \\
\hline \multirow[t]{4}{*}{ UTAG } & $0-10$ & 22 & 30 & 27 & 30 & 1 & 32 & 32 & 32 \\
\hline & $10.01-30$ & 7 & 2 & 4 & 1 & 3 & & & \\
\hline & $30.01-60$ & 2 & & 1 & 1 & 3 & & & \\
\hline & $60.01-100$ & 1 & & & & 25 & & & \\
\hline
\end{tabular}




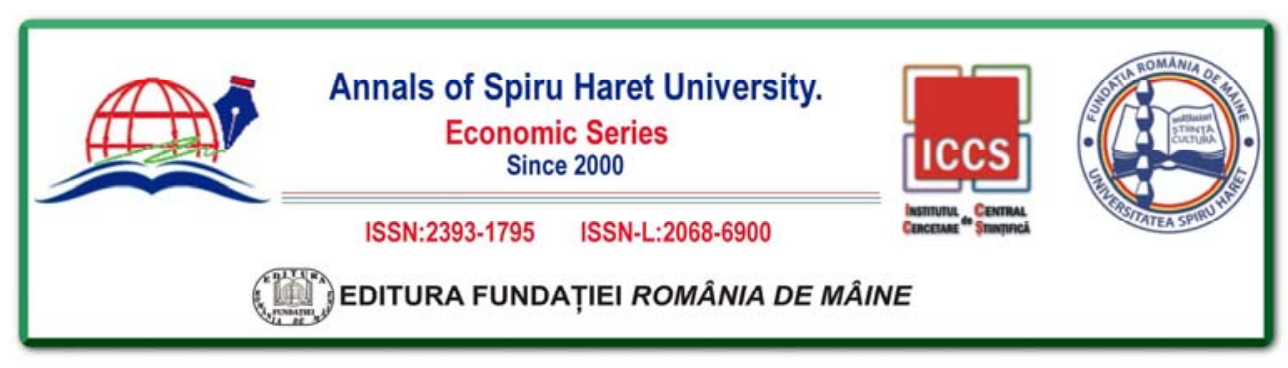

Issue $2 / 2018$

A higher level of concentration is specific for the Gagauzian ethnics, consequently in 24 localities the percentage share of the representatives of this ethnicity go over $60 \%$, which embodies $8.33 \%$ of the localities in which Gagauzes live, such as: Baurci, Cazaclia, Beșalma, Congaz, Tomai, Copceac, Cișmichioi etc. (ATUG).

\section{Conclusions}

Following the motives and objectives of this research, the analysed data allowed us to draw several main conclusions, to list implications and suggestions for further research:

1. The Southern Economical Region represents the most diverse national structure out of the economic regions of the country, represented by Moldavians, which embody the majority of nation and cohabit with other ethnicities: Gagauzes, Bulgarians, Russians, Ukrainians, Jewish, Germans, Roma, formed as a consequence of the geographical and geopolitical position, but as well due to the historic events which took place throughout the centuries.

2. The national structure of the region is determined mainly by the dominance of the territory by the Russian Empire as an aftermath of the victory over the Ottomans in the Russian-Turkish war of 1770-1776, by simulative measures and the forced population policy, applied by the tsarist government in that period.

3. The communist regime had a massive impact over the modifications of the ethnic structure, when within the limits of the region, as of the country generally, the idea of diversity of the ethnic structure was promoted and of denationalisation, moreover the migration of the population within the union republics being encouraged by the authorities, mixed marriages, schooling in Russian institutions etc., contributing this way to the growth of the population of Russians, Belarusians and Ukrainians.

4. In 1979-2014, the ethnic groups living in this territory manifested themselves differently, hence the proportionality of Moldavians, Gagauzes, Bulgarians, Romanians, Roma grows by $2.84 ; 2.96 ; 4.62 ; 4.67$ aned $0.07 \%$ respectively.

5. Some of the cohabiting nationalities are characterised by a constant decline, therefore although the density of Russians and Ukrainians rises between 1979-1989 by approximately $1.46 \%$ and $0.26 \%$ respectively (especially due to the migration of the specialists from the ex union republics), after the dissolution of the Soviet 


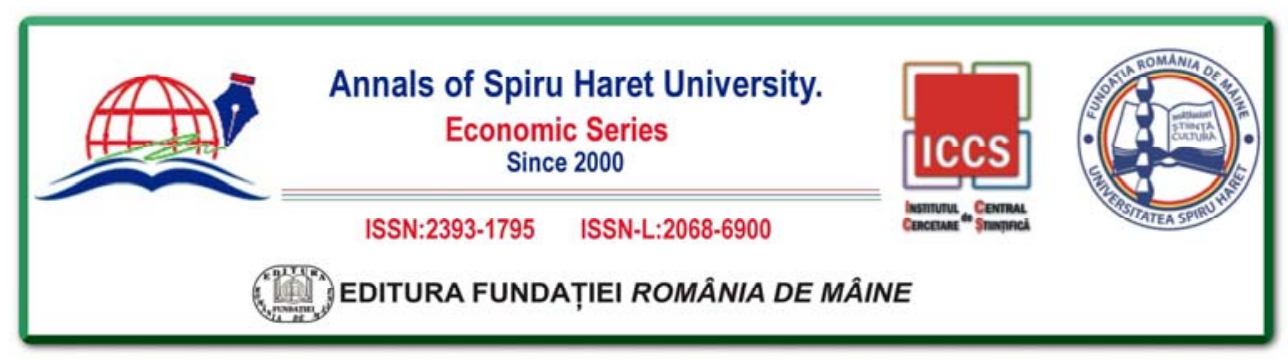

\section{Issue 2/2018}

Union, because of the economical and political instability, but also due to the higher and more attractive level of economic activity of the states of origin, a part of the population immigrates and the number of Russians and Ukrainians decreases in $1989-2014$ by $2.13 \%$ and $2.23 \%$ respectively.

6. The most significant changes in the national structure are registered in Taraclia district, where the proportions of Bulgarians increases by $25.91 \%$ in 2014 , comparing it to 1989 and it constitutes $66.11 \%$ (in 1979, Taraclia district did not exist and the localities included today into its component were part of Cahul, Vulcănești and Ceadîr Lunga) and ATUG in which the Gagauz proportionality grown in 2014 by $34.32 \%$, compared to 1989 and forms $83.78 \%$.

7. The national structure of the Basarabesca, Caușeni, Cimișlia, Ștefan Vodă, Leova district doesn't change significantly and is characterised by an increase during the whole period of investigation of predominance of Moldavians with values in limits between 2.07 and $17.03 \%$.

8. Cantemir and Cahul district are characterised by the decrease of predominance of Moldavians starting with 2004 and an increase in the predominance of Romanians with the same values, because after the gain of independence a majority of the population declares themselves as Romanians.

9. Due to the increased tolerance level manifested by the population in the region it manages to live in harmony with the representatives of other nationalities, thus in $98.14 \%$ of the cases the rural areas are multinational and only $1.85 \%$ homogeneous (all formed by Moldavians in proportion of a 100\%) Suhat, Craciun, Popovca, Cantemir district; Ursoaia Nouă and Ștefănești, Caușeni district; Victoria, Leova district. Approximately $91.98 \%$ of Russians, $84.57 \%$ of Ukrainians, $82.72 \%$ of Bulgarians and $82.10 \%$ of Gagauzs live separately, constituting up to $10 \%$ of the population in the localities.

10. Based on the idea of various ethnic component of the region, aiming to reduce the possibility of interethnic strained relations encouraged by the foreign contributions, it is necessary to increase the average level of life in the rural communities, through reduction of poverty, solving the issue of the access to drinkable water and to good quality roads, as well as improving the level of services and endowment of the residences. 


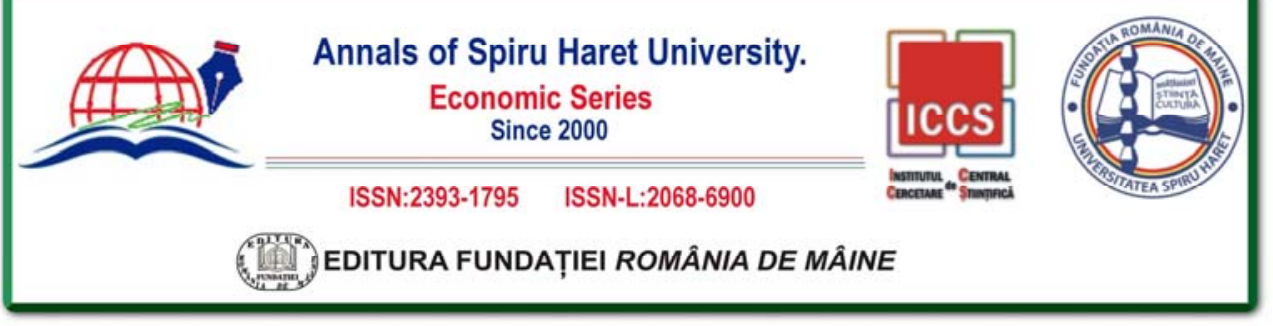

Issue $2 / 2018$

\section{References}

1. Arbure Zamfir C., Basarabia în secolul XIX, 1898, p. 91.

2. Bachinsky AD, The main stages of peasant-Cossack colonization of the Budjak steppe and the lower Danube in the XVIII - early XIX centuries. - Chisinau, 1966., p.326.

3. Berg L. K., Bessarabia: country, people, economy, Petrograd, 1918, p. 16.

4. Cantemir D., Descrierea Moldovei, Chișinău, 1473, p. 147.

5. Kabuzan VM, Population of Bessarabia and the region of the left-bank regions of Transnistria. - Chisinau, 1974, p. 24.

6. Matei C., Paladi G., SainsusV., Cartea Verde a Populației Republicii Moldova, Chișinău, 2009 , p. 30.

7. Matei C., Hachi M., Evoluția demografică a Republicii Moldova, Chișinău, 2014, p. 175

8. Mîtcu M., Hachi M., Populația rurală a Republicii Moldova: cercetări geodemografice, Chișinău, ASEM, 2008, p. 46.

9. Mokhov NA, Essays on the history of Moldovan-Russian-Ukrainian relations. Chisinau, 1961, p. 154-156.

10. Nistor I., "Așezările bulgare şi găgăuze din Basarabia," Analele Academiei Române, Memoriile secţiunii istorice, seria III, tomul XXVI, Bucureşti, 1944, p. 12.

11. Zagorodnaya E. M., Zelenchiuk V. S., Populația RSSM, Cartea Moldovenească, Chișinău, 1983, p. 75

12. Zagorodnaya EM, Zelenchuk VS, Population of the Moldavian SSR, Cartea Moldovenească, Chişinău, 1987, p. 10.

13. Zelenchuk VS, Population of Moldova, Chisinau, 1973, p.8

14. .** Itoghi Vsesoiuznoi perepisi naselenia 1979 goda po Moldavscoi SSR, tom.I, ceasti II, Chișinau, 1980.

15. *** Totalurile recensământului unional al populației din RSS Moldova și anul 1989, vol. I, cartea II, partea II, Chișinău, 1990.

16. *** Recensământul populației 2004, vol. 1, tom 1, Chișinău, 2006.

17. *** Recensământul populației 2004, vol. 2, tom 2, Chișinău, 2006.

18. www.statistica.md 
